\title{
Metafory konceptualne w niemieckich związkach frazeologicznych odnoszących się do ludzkich procesów poznawczych
}

\section{Streszczenie}

Artykuł porusza zagadnienie metafor konceptualnych jako podstawowego narzędzia ludzkiego poznania i konceptualizacji pojęć abstrakcyjnych. Opisuje sposób ich tworzenia oraz funkcjonowania w języku potocznym. Tekst zwraca uwagę na rolę związków frazeologicznych jako językowych sposobów realizacji metafor poznawczych. Analizie poddano wybrane związki frazeologiczne odnoszące się do sfery ludzkiego umysłu.

Słowa kluczowe: językoznawstwo kognitywne, metafory konceptualne, frazeologia, ludzkie poznanie, niemiecki

Celem przeprowadzonej w artykule refleksji jest próba nakreślenia, w jaki sposób zjawisko rozumienia, a także jego częściowego lub całkowitego braku jest tematyzowane i nazywane przez użytkowników języka niemieckiego. Rozważania dokonywane są na wybranych frazeologizmach należących do zasobu leksykalnego języka niemieckiego przy użyciu aparatu pojęciowego wywodzącego się z lingwistyki kognitywnej, w szczególności zaś metafory konceptualnej.

Nowe rozumienie metafory znajduje swój początek w pracach Lakoffa i Johnsona (2010: 29), którzy wyrazili opinię, że kategoryzowanie metafory jako zjawiska czysto językowego, często zarezerwowanego dla wysokich rejestrów językowych i poezji jest 
głęboko niewystarczające, a pełne opisanie tego zjawiska powinno doprowadzić nas do uwzględnienia jego raczej mentalnej natury służącej procesom postrzegania, myślenia i działania. W istocie cały system pojęć, którymi posługujemy się podczas operacji myślowych, ma mieć cechy metaforyczności. Metaforze przypada więc rola formuły centralnej nie tylko języka, ale stanowić ma ona bazowy mechanizm wszystkich ludzkich procesów mentalnych.

Jak przypomina Taraszka-Drożdż (2008: 1-2), metafora wyrasta na bazie sparowania dwóch pojęć, które pełnią rolę dziedzin konceptualnych, różnicowanych na dziedzinę docelową i źródłową. Na skutek sparowania metaforycznego cechy konceptualne z dziedziny źródłowej przenoszone są na dziedzinę docelową, którą chcemy w taki sposób opisać, zakodować, skategoryzować. Zwroty i wyrażenia są językowymi realizacjami, skutkami czy też odzwierciedleniami metafor konceptualnych, których funkcjonowanie pozostaje pod wpływem doświadczeń kulturowo-społecznych jednostki. Umotywowanie rozszerzeń konkretnych znaczeń wynika więc z osobniczej wiedzy na temat świata, pochodzącej z socjalizacji i przebywania w określonym kręgu kulturowym. Gemel (2016: 174) zgadza się z teorią, że takie ustrukturyzowanie i schematyczność metafory to podstawowa cecha jej wewnętrznego zorganizowania. Budowa metafory może zostać wytłumaczona przy użyciu konstruktu schemat-konkretyzacja, co niesie ze sobą potrzebę uznania metafory za strukturę, której zadaniem jest ogólne konceptualizowanie różnych konkretnych wypowiedzi. Przyjmując, że jednostkowe teksty funkcjonują jako postrzegalne demonstracje myśli, a metafory przyjmują rolę szerszego wzorca dla owych formułowanych wypowiedzi, należy konstatować, że schemat metaforyczny pełni jednocześnie funkcję konstruktu bazowego dla samego myślenia. Zaprezentowane wnioskowanie przebiega w ramach charakterystycznego dla kognitywistyki założenia pokrewieństwa struktur poznawczych i ich reprezentacji językowych.

Wydaje się, że następuje pewne zawieszenie pomiędzy aspektami zbieżnymi, wynikającymi z dzielonej przez wszystkich ludzi biologicznej natury, a różnicami kulturowymi. Wiele z metafor konceptualnych według badań Kövecsesa (2005: 63-64) wykazuje znaczną uniwersalność, z drugiej strony istnieją motywowane różnicami kulturowymi niezgodności w sposobie konceptualizacji. W tym miejscu rezonują myśli Edwarda Sapira (1963: 162), którego wyobrażenie o języku przywodzi na myśl rodzaj zbiornika przechowującego ogląd na świat, z którego członkowie danej społeczności na skutek procesu socjalizacji uczą się czerpać. Teoria zarysowanej wcześniej konceptualizacji świata zawartej w języku przypomina też o sformułowanym przez Bartmińskiego terminie językowego obrazu świata: ,pewien zespół sądów mniej lub bardziej utrwalonych w języku, zawarty w znaczeniach wyrazów lub przez te znaczenia implikowany, który orzeka o cechach i sposobach istnienia obiektów świata pozajęzykowego" (Bartmiński, 2009: 16).

Przywołując na powrót myśl kognitywistyczną, możemy założyć, że język pozostaje w ścisłym związku z procesem poznania i jest odpowiedzialny za przekazywanie kulturowo motywowanego mechanizmu posługiwania się pojęciami. Wiraszka (2008: 204-205) uzupełnia, że językoznawstwo kognitywne uwzględnia także rolę ludzkiego ciała, w którym nasz aparat poznawczy jest przecież osadzony. Sposób, w jaki rejestrujemy otaczającą nas rzeczywistość i na skutek zebranych doświadczeń rozwijamy opisujące 
ją koncepty, wynika z naszego biologicznego wyposażenia, co w konsekwencji znajduje również swoje przełożenie na posługiwanie się językiem. Tę zależność rozpoznać możemy w samych metaforach przejmujących cechy cielesne, wymierne i materialne - a więc charakteryzujące zjawiska znane ze sfery cielesności - by przypisać je do zjawisk abstrakcyjnych, mieszczących się w obszarze, do którego nie mamy zmysłowego dostępu. Pietrzak-Porwisz (2007: 32-33) przedstawia trzy etapy odwzorowania metaforycznego:

- ustalenie bytów ontologicznych w obydwu domenach,

- projekcja topologiczna,

- użycie logicznej struktury wiedzy z domeny źródłowej.

W fazie pierwszej następuje ustalenie odpowiadających sobie bytów, czynności i stanów w obydwu domenach pojęciowych. W drugim etapie projekcji topologicznej do domeny docelowej przenoszone są schematy wyobrażeniowe domeny źródłowej, które należy postrzegać jako relatywnie proste struktury pojęciowe kształtowane podczas kontaktu danej jednostki ze światem. W ostatniej części tego procesu w obrębie domeny docelowej budowane są wzorce wnioskowania i logiczne rozwinięcia, analogiczne do tych, które obecne są w domenie źródłowej. Cała wewnętrzna logika, formująca wewnętrzne związki schematów wyobrażeniowych zostaje niejako skopiowana do domeny docelowej.

Jak wcześniej zauważono, kreowanie metafory konceptualnej odbywa się dzięki wprowadzeniu osi relacyjnej pomiędzy domenami docelową i źródłową - rodzi to ważne pytanie, czym w ogóle są rzeczone domeny i jak należy je rozumieć. Z propozycją odpowiedzi wychodzi Gemel (2015: 92), którego zdaniem domena to szczególne pole konceptualizacji treści językowych, bazujące na relacji do treści pojęciowej denotowanej i konotowanej, związanych z danym wyrażeniem. Ogniskuje ona tym samym szerokie spektrum komponentów o naturze:

- konceptualnej,

- empirycznej,

- konotacyjnej, pośród których można wyróżnić te pragmatyczne i kulturowe.

Paroń (2011: 44) prezentuje wybrane typy metafor wyróżnione przez Lakoffa i Johnsona. Na podstawie tej typologii możemy również zobaczyć, jak mogą się kształtować domeny źródłowe:

- metafory orientacyjne - jedno pojęcie nadpisuje orientację przestrzenną drugiej treści pojęciowej (na przykład więcej w górę, przeszłość $w$ tyl),

- metafory ontologiczne - zakorzenione w urzeczowieniu bytów niekonkretnych (na przykład umyst to rzecz),

- metafory strukturalne - pojęciu drugiemu pojęcie pierwsze przydaje strukturę metaforyczną.

Przykład użyty przez Lakoffa oraz Johnsona i przytoczony przez Paroń - Argumentowanie to wojna - może budzić pewne wątpliwości czy nawet skłaniać do refleksji nad ogólną prawidłowością teorii metafor konceptualnych. Warto bowiem zauważyć, że tutaj zarówno domena źródłowa, jak i docelowa są pojęciami abstrakcyjnymi, istnieje więc dużo słabsze niż w poprzednich egzemplifikacjach nadanie cech materialnych pojęciu nierzeczywistemu. W tym miejscu chciałbym wysunąć własne ostrożne przypuszczenie, że sytuacja sparowania dwóch domen pojęć abstrakcyjnych nie przeczy słuszności teorii 
metafor. Wydaje się niepozbawionym przesłanek zwróceniem się w kierunku konotacji, przynależących według Lakoffa i Johnsona do treści pojęciowych. W tym miejscu godzi się objaśnić, czym są konotacje, a także jaką rolę odgrywają w mojej opinii dla wyjaśnienia możliwych niekonsekwencji teorii metafor oraz jak wiążą się z użytym wcześniej terminem językowego obrazu świata.

Konotacje podług słów Grzegorczykowej (2004: 79) to: „wyobrażenia i przekonania wiązane przez mówiących z nazywanymi zjawiskami”. Maciołek (2013: 15) uznaje konotacje obok między innymi cech fleksyjnych i słowotwórczych języka, słownictwa i frazeologii, utworów literackich i przysłów, semantyki i etymologii za podstawowe zjawiska będące nośnikami językowego obrazu świata. Jak sugerowano wcześniej, można domniemać, że tworzenie metafor czerpiących z dziedzin pojęć abstrakcyjnych jest możliwe, ponieważ pojęcia abstrakcyjne pełniące funkcję dziedziny źródłowej są skonotowane z pojęciami obserwowalnymi. I tak wojna z wcześniejszego przykładu, która sama nie jest obiektem materialnym, jest rozpoznawalna dzięki cechom i konotacjom, które odsyłają użytkownika języka do mierzalnych pojęć, takich jak krew czy śmierć (konkretyzowana jako ustanie funkcji życiowych podmiotu).

Warto dodać, że produktywnym narzędziem językowego opisu rzeczywistości oprócz metafory jest metonimia, czyli przeniesienie nazwy jednej rzeczy na inną, na przykład rusz głowa - w podanym frazeologizmie rozum i kompetencje intelektualne zostały metonimicznie wymienione na część ciała osadzoną na szyi. Lakoff i Johnson (2010: 68-69) różnicują metaforę i metonimię pod względem funkcji, które im przypadają i tak metafora jest, jak zostało to wielokrotnie opisane, narzędziem zrozumienia, a metonimia spełnia funkcję prymarnie desygnacyjną i pozwala na ukonkretnienie pojęcia, na które wskazujemy. Metonimia podobnie jak metafora pozostaje częścią naszego potocznego myślenia i czerpie z zebranych doświadczeń, strukturyzując nasze myślenie i działanie.

$\mathrm{Na}$ frazeologię jako obszar, który trafnie pokazuje, że dane społeczności językowe lubią posługiwać się różnymi obrazami i symbolami, ukazującymi sposób konceptualizacji rzeczywistości typowy dla tych grup, wskazują Sava i Appelkvist (2013: 177-178). Niektóre obszary słownictwa wykorzystywane są z wyższą częstotliwością w celu obrazowania i uplastycznienia wypowiedzi - stąd do celów frazeologizacji zauważalnie często wykorzystywana jest metaforyka bazująca na częściach ciała, zwierzętach, insektach, słownictwie militarnym, religijnym lub utrwalonym w tekstach mitologicznych. Przykładając do naszych rozprawiań ideę metafor konceptualnych, możemy powiedzieć, że wymienione obszary leksykalne przyjmują niejednokrotnie rolę domeny źródłowej, przy czym możemy również wskazać na obszary leksykalne podatne na procesy metaforyzacji, czyli występujące w funkcji domeny docelowej; są to na przykład śmierć, pieniądze, miłość czy choćby sfera ludzkich myśli.

Sava i Appelkvist zauważają, że od lat dziewięćdziesiątych daje się stwierdzić istnienie zbliżenia obszaru badań nad metaforami z frazeologią. $Z$ tego powodu rozważania podejmowane nad powstawaniem i znaczeniem frazeologizmów zaczęły obejmować także pytania dotyczące motywujących je metaforycznych konceptów i w konsekwencji roli, jaką odgrywają one podczas konstytuowania obecnych w języku frazemów. Sava i Appelkvist (2013: 179) piszą, że skoro teoria metafor konceptualnych wspiera się na 
przekonaniu, że ludzkie procesy mentalne ustrukturyzowane są zgodnie z procesami metaforyzacji, a ponieważ metaforyzacji przypada także zasadnicza rola w procesie tworzenia frazeologizmów, zasadniczość teorii kognitywnej mogłaby zostać poddana weryfikacji, a jej przejawy unaocznieniu dzięki wskazaniu na zbieżności i różnice w zasobach frazeologicznych różnych języków. Poza tym, jak wykłada Nowakowska (1991: 361), związki frazeologiczne umożliwiają spostrzeżenie cech kulturowych swoistych dla danej grupy językowej, co dokonuje się dzięki ich depozycyjnej właściwości wobec realiów minionych, są one świadectwami obowiązującej niegdyś obyczajowości, spuścizny artystycznej oraz interakcji z otaczającą naturą.

Burger (2003: 11) zalicza do związków frazeologicznych wszystkie wyrażenia, które spełniają warunek polileksykalności oraz stałości semantyczno-syntaktycznej, co powoduje, że możliwości zastąpienia choćby jednego elementu z kilku budujących całe wyrażenie, bez modyfikacji czy usunięcia znaczenia wyjściowego, pozostają ograniczone lub w ogóle nie istnieją. Jako pewna całość funkcjonują one w użyciu danego języka oraz jako pewna spójna jednostka znalazły miejsce w słownikach, przez użytkowników systemu językowego są więc raczej reprodukowane i odtwarzane aniżeli wymyślane i układane spontanicznie. Fleischer (1982: 35) prezentuje zgodne z Burgerem stanowisko dotyczące polileksykalności, względnej stałości, reprodukowalności oraz zaleksykalizowania związków frazeologicznych. Dodatkowo wskazuje on na ich idiomatyczność. Znaczenie całości wyrażenia nie wynika z sumy tworzących go elementów (na przykład sens związków frazeologicznych etwas auf Eis legen lub Eine Fahrt ins Blaue, oznaczających kolejno opóźnienie, zwłokę w jakimś przedsięwzięciu i podróż w nieznanym kierunku, nie wynika w oczywisty i w bezpośredni sposób z należących do nich leksemów). W ramach wszystkich tych warunków może wystąpić pewna gradacja i tak występować mogą frazemy prezentujące bardziej lub mniej zaznaczony stopień stałości lub idiomatyczności, a także różnie może wyglądać ich budowa, jeśli zaczniemy różnicować pomiędzy tworzącymi je słowami, które mogą być wyrazami niosącymi własną treść lub tylko spełniającymi odpowiednią funkcję.

Biorąc pod uwagę wymienione wcześniej cechy Malá (2009: 40-41) zalicza do grupy związków frazeologicznych takie zwroty, jak:

- idiomy, cechujące się wysokim stopniem metaforyzacji, często występujące w języku niemieckim w formie nominalnej (na przykład ein alter Hase, ein Mann von Wort), w tym nazwy własne (na przykład der rote Halbmond), czasownikowej (jdm. Sand in die Augen streuen), jako pary wyrazowe (na przykład Hab und Gut, kurz und bündig) lub jako zestawienia i porównania (jdm. wie ein Schatten folgen; heimlich, still und leise);

- przysłowia, które często zawierają naukę moralną, wskazując na określony związek przyczynowo-skutkowy (na przykład will man den Hund prügeln, findet sich immer ein Stock);

- skrzydlate słowa i aforyzmy (na przykład Leben und leben lassen);

- wyrażenia czasownikowo-rzeczownikowe (na przykład zur Kenntnis nehmen);

- kolokacje (na przykład die Stille herrschte).

Analizowane w niniejszym tekście związki frazeologiczne będą odnosiły się w swym znaczeniu do powiązanych ze sobą procesów poznawczych i potrzebnych do ich zaistnie- 
nia osobniczych kompetencji mentalnych (predyspozycja umysłowa, pamięć, myślenie, rozumienie i jego brak, wnioskowanie prawidłowe i nieprawidłowe).

Skoro metafory uważane są przez kognitywistów za jeden z centralnych mechanizmów postrzegania oraz rozumienia, a także umożliwiają uchwycenie pojęć nierzeczywistych w języku, zasadna wydaje się analiza, w jaki sposób procesy te wykorzystywane są do opisu samych procesów myślowych. Budujące badany materiał frazeologizmy pozwolą na refleksję o metamyślowej specyfice, która ukaże nam, w jaki sposób konceptualizowane są w języku niemieckim procesy poznawcze, a więc jakie metafory są w tym zakresie używane.

1. Predyspozycje umysłowe:

1a. Zdolności kognitywne jako POLE WIDZENIA - przedstawienie zdolności pojmowania człowieka jako horyzontu wiąże się też z wyobrażeniem o myśleniu jako postrzeganiu pewnych faktów i dostrzeganiu powiązań między nimi, a więc porównaniu rozumienia do zmysłu wzroku. Im szerszym dysponujemy polem widzenia, tym więcej zobaczymy; im szerszy nasz mentalny horyzont, tym więcej zrozumiemy:

über jemandes Horizont gehen - pole widzenia przedstawiane jest dosłownie jako zbyt niskie; treści poruszają się ponad czyimiś możliwościami ich zauważenia;

einen engen/beschränkten Horizont haben - pole widzenia jest portretowane w tej metaforze jako niezbyt rozległe w poziomie;

ein Brett vor dem/vorm Kopf haben - pole widzenia jest skutecznie utrudnione przez przeszkodę;

weitsichtig sein - być dalekowzrocznym, przewidującym, wnioskującym na przyszłość z bieżących przesłanek;

mit Weitblick - posiadanie sporych możliwości, oglądu obejmującego znaczną powierzchnię;

vernagelt sein - wysoki poziom ograniczenia możliwości spoglądania, a więc myślenie wysoce zredukowane.

1b. Zdolności kognitywne reprezentowane za pomocą zastąpienia w metaforze mózgu przez SUBSTANCJĘ ORGANICZNĄ:

etwas in der Birne haben - metafora wymieniająca głowę na obraz gruszki; warto zauważyć, że głowa pełni funkcję metonimii, symbolizując intelekt - niezauważalne więc gołym okiem zdolności poznawcze unaoczniane są za pomocą owocu;

bematscht in der Birne sein - niskie zdolności kognitywne odzwierciedla niepożądana konsystencja wewnętrzna miąższu;

eine Sülze im Kop haben - nieefektywnie działający umysł opisany jako galareta;

Stroh im Kopf haben - słabo rozwinięte zdolności intelektualne unaocznione przez obraz słomy;

Spreu im Kop haben - brak nowatorskości myślenia, wtórność i bezwartościowość obrazowane przez wskazanie na obecne w czyjejś głowie plewy;

ein Holzkopf sein - brak nieschematyczności myślenia reprezentowany przez obraz głowy utoczonej z drewna;

Grütze im Kopf haben - to wyrażenie może być interpretowane zarówno jako posiadanie sprawnie działającego, jak i niezbyt lotnego intelektu. 
Warto zauważyć, że natrętne myśli i plany niemożliwe do realizacji ukazywane są za pomocą metaforyki robactwa, na przykład Raupen im Kopf haben lub Floh im Ohr haben.

1c. Brak odpowiednio rozwiniętych zdolności kognitywnych symbolizowany jest przez ewidentnie zaznaczone UBYTKI I NIEDOSKONAŁOŚCI MATERIALNE:

nicht alle Nieten an der Hose haben - konstrukcja spodni pozbawiona nitów jest bezsensowna;

nicht alle Tassen im Schrank haben - opustoszała szafka nie spełnia swojego podstawowego celu;

einen Riss in der Birne haben - brak zaznaczony jest wcięciem, rozdarciem;

bei jdm ist eine Schraube locker - poluzowana śruba grozi rozpadem całej konstrukcji; nicht alle im Karton haben - ewidentny brak, niewykorzystanie przestrzeni;

bei jdm. ist es unterm Dach nicht ganz richtig - dach postrzegany jako metonimia wobec całości domu, który symbolizuje głowę, w której stwierdza się istnienie nieporządku i rozmaitych uchybień;

einen Webfehler haben - błąd reprezentujący niedoskonałości myślenia.

1d. Zdolności intelektualne jako NARZĘDZIA/INSTRUMENTY POMIAROWE:

keine Peilung haben - niskie kompetencje umysłowe zrównane z niedostatecznym wyposażeniem;

eine lange Leitung haben - wydłużony czas rozumienia obrazowany długością przewodu;

auf Draht sein - podobny wizerunek okablowania - rozumienie warunkowane odpowiednim oprzyrządowaniem.

2. Pamięć - analiza zebranych związków frazeologicznych pokazuje, że jest ona konceptualizowana jako POJEMNIK/TABLICA/STOJAK. W zebranych frazeologizmach takie traktowanie i postrzeganie pamięci staje się widoczne głównie dzięki towarzyszącym jej czasownikom:

jemanden/etwas aus dem Gedächtnis tilgen - wymazanie czegoś z pamięci na kształt usuwania napisu z tablicy;

in seinem Gedächtnis kramen - poszukiwanie czegoś w pamięci jak w przepastnym pojemniku;

ins Gedächtnis holen - pamięć przedstawiana znowu jako zamknięta przestrzeń, do której coś może zostać wniesione;

im Gedächtnis hängen bleiben - coś zostaje zawieszone w pamięci, jakby była stojakiem;

ein Gedächtnis/Hirn/Gehirn wie ein Sieb haben - pamięć jako sito, czyli pojemnik o dużej przepuszczalności.

\section{Proces myślenia jako analizowania danych:}

3a. Proces myślenia jako RUCH, myśli jako OBIEKTY W RUCHU:

auf etwas kommen; draufldarauf kommen - myślenie w poszukiwaniu odpowiedzi, rozwiązania jako celowy ruch prowadzący w kierunku czekającego na drodze wniosku, zrównanego ze statycznym obiektem;

sich (D.) durch den Kop gehen lassen - myśl jako obiekt wprawiany w ruch;

Gedanken gehen in diese Richtung - kolokacja pokazująca myśli dążące aktywnie do wyznaczonego celu, poruszające się linearnie; 
Gedanken geistern herum/drehen sich um etwas/kreisen - te kolokacje pokazują, że myśli postrzegane są jako obiekty, a myślenie to ich ruch okrężny;

Sich (D.) etwas einfallen lassen - pomysł/rozwiązanie/myśl przez czasownik stawiane są na równi z obiektem, który podlega sile ciążenia.

3b. Proces intensywnego myślenia jako FIZYCZNY WYSIŁEK/TORTURA:

jmdm. raucht der Kopf-myślenie objawiające się jako ukryty pożar wewnątrz głowy, sygnalizowany przez spełniający rolę indeksu dym;

sich den Kopf zerbrechen - myślenie jako aktywność drastyczna, sprawiająca ból;

sich das Hirn/Gehirn verrenken - myślenie jako aktywność grożąca kontuzją;

sich das Hirn/Gehirn zermartern - aktywność drastyczna, równa zniszczeniu i torturze.

\section{Brak rozumienia i popełnienie błędu:}

4a. Informacja przedstawiana jako ELEMENT WIZUALNY/AUDYTYWNY - ta metaforyka powiązana jest $\mathrm{z}$ metaforą konceptualną wypracowaną w punkcie 1a; wiedza jako obiekt dający się stwierdzić zmysłowo - za pomocą wzroku lub słuchu; brak rozumienia to brak możliwości ujrzenia lub usłyszenia wyznaczonego obiektu:

sich kein Bild von etwas machen können - obecne wrażenie wzrokowe;

von Tuten und Blasen keine Ahnung haben - odczasownikowe rzeczowniki związane ze sferą słuchu;

keinen blassen Schimmer haben - główny rzeczownik i opisujący go przymiotnik jednoznacznie znajdują się w związku ze strefą doznań wzorkowych;

keinen blassen Dunst von etwas haben - w szczególności przymiotnik opisujący barwę mgły/wyziewu wskazuje na postrzeganie za pomocą narządu wzroku;

jemandem schleierhaft sein - czegoś nie rozumiemy - obiekt jest zasłonięty, jest poza zasięgiem wzroku;

im Nebel stehen - nasze postrzeganie jest zaburzone przez obecność mgły;

jemandem/sich etwas vor Augen führen - rozumienie zrównane z widzeniem, czego nie dostrzegą oczy, tego nie rozumiemy.

4b. Stan mentalny osoby nierozumiejącej sportretowany przez jej WYGLĄD ZEWNĘTRZNY I KONKRETNĄ SYTUACJĘ:

nackt in den Erbsen stehen - niezrozumienie i wynikające z niego poczucie zdezorientowania, konsternacji, a także ośmieszenia zostaje zobrazowane za pomocą obrazu nagości, a uwypuklone przez obecność nieprzystającego do kontekstu warzywa;

wie ein Schwein ins Uhrwerk schauen/blicken/gucken/glotzen; dasitzen/dastehen wie ein Schwein vorm/vor dem Uhrwerk - nierozumienie, które może wynikać z ograniczonych zdolności poznawczych zostaje oddane przez zarysowanie opartej na kontraście relacji pomiędzy świnią reprezentującą niższe niż przeciętnie przypisywane człowiekowi zdolności intelektualne a mechanizmem zegarka, który w swym przeznaczeniu skierowany jest do istoty ludzkiej, wyposażonej w odpowiednio rozwinięty aparat poznawczy;

dastehen/aussehen wie ein lebendiges Fragezeichen - konstruowanie metafory przy użyciu innego symbolicznego znaku, tj. znaku zapytania, który sam wprawdzie nie jest skonkretyzowanym obiektem, ale przez utrwalone kulturowo konotacje $\mathrm{z}$ niepewnością i poszukiwaniem odpowiedzi został przy połączeniu z przymiotnikiem lebendig wykorzystany do opisu niewidocznego stanu konfuzji i nierozumienia; 
ein Waisenknabe/Waisenkind in etwas sein - osamotnienie mentalne i słabość intelektualna zostają zaprezentowane przy odniesieniu do relacji społecznej i niekorzystnego położenia bezbronnego, osieroconego dziecka;

(wie) Chinesisch für jemanden sein/für jmdn. böhmische Dörfer sein/etwas kommt jmdm. böhmisch vorletwas kommt jmdm. spanisch vor - brak zrozumienia i poczucie dyskomfortu zrównywane jest z brakiem opanowania danego języka; coś, czego nie rozumiemy, to coś zlokalizowanego poza naszym kręgiem językowo-kulturowym; choć język jest zjawiskiem niematerialnym, głoski i graficzne symbole będące jego dostrzegalnymi przejawami są dostrzegalne wzrokowo i słuchowo.

4c. Pomyłka rozumiana jako ZABURZONA RELACJA PRZESTRZENNA

im falschen Zug sitzen

auf dem falschen Dampfer sein

auf dem falschen Gleis sein

auf der falschen Hochzeit tanzen

W nawiązaniu do metafory konceptualnej 3a operowanie myślami przypomina obiekty znajdujące się w ruchu okrężnym lub liniowym; wszystkie wymienione wyżej związki frazeologiczne stworzone zostały w oparciu o wyobrażenie, że błąd to znajdowanie się w nieprawidłowym miejscu, niedopasowanie lokalizacji, przebywanie na drodze nieprowadzącej do celu.

auf dem Holzweg sein - błąd jako przebywanie na ścieżce nieprowadzącej do prawidłowego rozwiązania;

etwas in den falschen Hals/die falsche Kehle bekommen - pomyłka opisana została w tych przedstawionych somatyzmach jako wpadnięcie do nieprzeznaczonej do tego części ciała;

(völlig) neben den Schuhen stehen - metafora konkretyzująca i objaśniająca nieprawidłowy sposób wnioskowania przez sprowadzenie tego mentalnego procesu do sytuacji znanej z rzeczywistości materialnej, do obserwowalnego stanu rzeczy; niemniej zrozumienie tej metafory nie jest niewolne od rozumienia wpływów i zależności kulturowych, wyuczonych w procesie socjalizacji wzorców zachowań (podstawowa wiedza na temat istnienia butów i ich przeznaczenia, która nie jest obecna we wszystkich kulturach globu).

4d. Brak rozumienia i pomyłka jako NIEPRAWIDŁOWY MANEWR/NIEDOSKONAŁOŚCI FIZYCZNE - niejako w oparciu o metaforę konceptualną wyekscerpowaną w podpunkcie 4c; nieosiągnięcie zrozumienia utożsamiane jest z nieprawidłowo wykonanym ruchem w przestrzeni lub niemożliwością wykonania ruchu, który jest niezbędny do osiągnięcia danego celu:

zu hoch für jemanden sein/jemandem zu hoch sein - wysiłek kognitywny jest dla danej osoby zbyt duży; zostaje on wyrażony przy pomocy obrazowania przestrzennego i implikacji zbyt dużego wysiłku fizycznego;

nicht durchsteigen - brak rozumienia to brak możliwości wykonania odpowiedniego ruchu, przedostania się na drugą stronę, wspięcia się;

danebenhauen/sich verhauen - czasowniki, które ze względu na mocno rozbudowaną warstwę obrazowości zostały uwzględnione w analizowanym materiale, ukazują minię- 
cie się z poprawną odpowiedzią, nieuchwycenie poprawnego wniosku, a więc pomyłka interpretowana jest jako ruch prowadzący obok celu.

5. Rozumienie - prawidłowe wnioskowanie, rozpoznanie powiązań między faktami, ustalenie stanu rzeczy zgodnego z rzeczywistością; przedstawione obrazy odnoszące się do sytuacji zrozumienia danej kwestii bazują na dwóch komponentach:

- nagłe, szybkie, dokonujące się jakby bez zapowiedzi,

- stwierdzalne przez towarzyszące im bodźce wzrokowe lub słuchowe.

5a. Rozumienie jako NAGŁY INCYDENT ZAUWAŻALNY DŹWIĘKOWO:

bei jdm platzt der Knoten - czasownik platzen kreuje obraz nagłej zmiany; pęknięcie związane jest z powstaniem wyraźnego hałasu, huku;

ein Aha-Erlebnis haben - proces rozumienia, który dokonał się z sukcesem, sprowadzony zostaje do symptomatycznej dla tego wydarzenia interiekcji Aha!; następuje tu metonimiczne zastąpienie samego procesu przez skorelowany z nim objaw;

bei jemandem ist der Groschen gefallen - upadek monety na podłoże powoduje powstanie słyszalnego dźwięku;

wissen, was die Glocke/Uhr geschlagen hat - obraz odnoszący się do dźwięku wydanego przez dzwon lub zegar;

bei jdm. klingelt es - czasownik onomatopeiczny.

5b. Rozumienie jako nagły incydent zauważalny WZROKOWO:

einen Geitesblitz haben - słowo bazowe zastosowanego złożenia referuje do nagłego rozbłysku;

jemandem geht ein Licht aufljemandem geht eine Laterne auf - stan zrozumienia sygnalizowany jest nagłą iluminacją;

es funkt - struktury mózgowe i towarzyszące im procesy porównane zostają do procesów elektromechanicznych.

To wyobrażenie wiedzy i rozumienia jako światła i oświecenia pozostaje w zgodności ze zwrotami oznaczającymi wytłumaczenie, objaśnienie skomplikowanych kwestii, na przykład jdm ein Licht aufstecken, ein neues Licht auf etwas werfen, Licht ins Dunkel bringen, an Tageslicht bringen .

Konkludując, możemy stwierdzić, że teoria metafor konceptualnych na moment obecny nie stanowi jednoznacznego rozwiązania pytania o konceptualizowanie pojęć abstrakcyjnych, której słuszność byłaby potwierdzona pond wszelką wątpliwość, ale niewątpliwie stanowi godne dalszych badań, obiecujące i wszechstronne narzędzie, służące analizie procesów poznawczych oraz ich językowych przejawów. Same procesy myślowe, takie jak postrzeganie, zapamiętywanie, analizowanie i rozumienie, opisywane są za pomocą wyrażeń językowych, u których podstawy znajdują się wyróżnione w części empirycznej wyobrażenia metaforyczne. Sfera myśli człowieka w języku portretowana jest za pomocą metafor z aspektem świetlnym, przestrzennym i dźwiękowym. Nieobca tej dziedzinie pozostaje też metaforyka robactwa, drogi i ruchu liniowego oraz okrężnego. Wysiłek intelektualny często konkretyzowany jest dzięki domenie źródłowej wysiłku fizycznego, a osobnicze predyspozycje porównane zostają do wyposażenia technologicznego.

W podpunktach $4 \mathrm{~b}$ oraz $4 \mathrm{c}$ zauważalna jest metaforyzacja, w której domena źródłowa jest bardziej skomplikowana, stanowi ją wielowątkowy obraz czerpany z sytuacji 
osadzonej w danej kulturze. By prawidłowo ów obraz interpretować, niezbędna jest wiedza kulturowa nabywana przez egzystowanie w ramach konkretnej grupy społecznej. Wydawać by się mogło, że jest to słabość teorii metafor, że poszczególne abstrakcyjne wyobrażenia opierane są na równie ciężko definiowalnym konstrukcie jak kultura, która według Everetta (2019: 367) ,jest milczącą wiedzą i otwartym praktykowaniem ról społecznych, wartościami oraz sposobami ich współdzielenia przez daną społeczność”. Warto jednak pamiętać, że niedostosowanie się do reguł i wartości, które same w sobie stanowią konstrukt kumulatywny niesiony w obrębie danej społeczności, pociąga za sobą bardzo realne, odczuwalne konsekwencje. Zastosowanie pojęcia abstrakcyjnego w funkcji domeny źródłowej jest też możliwe dzięki zawartym w ich treści pojęciowej konotacjom, prowadzącym do pojęć konkretnych - myślę, że możemy zaryzykować stwierdzenie, że tak naprawdę domenę źródłową stanowią w dalszym ciągu owe materialne pojęcia lub obserwowalne wydarzenia, które pozostają niejako w ukryciu przez sieć konotacji.

Dalsze badania metafor konceptualnych mogą przynieść odpowiedź na pytanie o uniwersalia motywujące procesy konceptualizacyjne oraz wyobrażenia specyficzne kulturowo. Na podstawie wybranego w tekście obszaru, który został poddany analizie, można stwierdzić, że metafora poznawcza stanowi wysoce produktywne narzędzie rekonstruowania językowego obrazu świata.

\section{Bibliografia}

Bartmiński J. (2009), Językowe podstawy obrazu świata, Lublin.

Burger H. (2003), Phraseologie. Eine Einführung am Bespiel des Deutschen, Berlin.

Everett D.L. (2019), Jak powstał język. Historia największego wynalazku ludzkości, Warszawa.

Fleischer W. (1982), Phraseologie der deutschen Gegenwartssprache, Lipsk.

Gemel A. (2015), Językowy model poznania. Kognitywne komponenty w kontynentalnej filozofii języka, Łódź.

Gemel A. (2016), Codzienność metafory w perspektywie kognitywistycznej. Próba krytycznej analizy, „Nauki o Wychowaniu. Studia Interdyscyplinarne”, t. 2, nr 1.

Grzegorczykowa R. (2004), Idee kognitywizmu jako podstawa badań porównawczych w zakresie semantyki, „Etnolingwistyka. Problemy Języka i Kultury”, nr 16.

Kövecses Z. (2005), Metaphor in Culture, Universality and Variation, Cambridge.

Lakoff G., Johnson M. (2010), Metafory w naszym życiu, Warszawa.

Maciołek M. (2013), Kształtowanie się nazw owadów w języku polskim: procesy nominacyjne a językowy obraz świata, Katowice.

Malá J. (2009), Stilistische Textanalyse. Grundlagen und Methoden, Brno.

Nowakowska A. (1991), Obraz świata zwierząt we frazeologii polskiej i francuskiej, „Poradnik Językowy", z. 9-10.

Paroń K. (2011), Rzeczywistość to metafora-próba kognitywnej analizy metafor w felietonach Jerzego Urbana, „Acta Universitas Lodziensis. Folia Literraria Polonica”, t. 14, nr 1. 
Pietrzak-Porwisz G. (2007), Metonimia i metafora w strukturze semantycznej szwedzkich somatyzmów hjärta ,serce”, ansikte „twarz” i hand „,ręka”, Kraków.

Sapir E. (1963), Language, [w:] Selected writings of Edward Sapir in Language, Culture and Personality, Los Angeles.

Sava D., Appelkvist Å. (2013), Zur Konzeptualisierung des Ablebens. Versprachlichungsmuster in der deutschen, rumänischen und schwedischen Phraseologie, „Germanistische Beiträge", t. 33.

Taraszka-Drożdż B. (2008), Teoria metafory konceptualnej w nauczaniu języka obcego, [w:] J. Florczak, M. Gajos (red.), Językoznawstwo a dydaktyka języków obcych, Warszawa.

Wiraszka Ł. (2008), Językoznawstwo kognitywne: w poszukiwaniu humanistycznej koncepcji języka, „Studia ad Fontes Humaninatits Europeae Pertinentia”, t. 1.

\section{Abstract \\ Conceptual metaphors in selected German phraseological units referring to human cognition}

The aim of the paper is to elaborate on conceptual metaphors as a fundamental scheme of human cognition and conceptualization of abstract thinking. The article describes the way they are created and how they exist in the everyday language. Attention has been predominantly directed to phraseological units that often are used to capture the metaphors and express the underlying concepts in the language. The analysis included phrasological units referring to the sphere of human mind.

Keywords: cognitive linguistics, conceptual metaphors, phraseology, human cognition, German 